\title{
Sedimentary evolution and ecosystem change in Ahémé lake, south-west Benin
}

\author{
Ernest Amoussou ${ }^{1,2}$, Henri S. Totin Vodounon ${ }^{1,2}$, Expédit W. Vissin ${ }^{2}$, Gil Mahé ${ }^{4}$, and \\ Marc Lucien Oyédé ${ }^{3}$ \\ ${ }^{1}$ Department of Geography and Land Use Planning, University of Parakou, BP 123 Parakou, Benin \\ ${ }^{2}$ Laboratory Pierre PAGNEY, Climate, Water, Ecosystems and Development (LACEEDE), \\ University of Abomey-Calavi, 03 BP1122 Cotonou, Benin \\ ${ }^{3}$ Department of Earth Sciences, Faculty of Technical Sciences University of Abomey-Calavi, Benin \\ ${ }^{4}$ IRD, Laboratory HydroSciences of Montpellier, University of Montpellier 2, \\ Case courrier MSE, Place Eugène Bataillon, 34095 Montpellier CEDEX 5, France
}

Correspondence: Ernest Amoussou (ernestamoussou@gmail.com)

Received: 14 June 2017 - Revised: 14 February 2018 - Accepted: 19 February 2018 - Published: 16 April 2018

\begin{abstract}
Tropical moist ecosystems, such as Ahémé lake, south-west Benin, are increasingly marked by water degradation, linked with the activities of increasing riparian populations. The objective of this study is to analyze sedimentary dynamics and its influence on the changing ecosystem of Ahémé lake from 1961-2010. Data used to carry out the study are records of precipitation, flows, turbidity, suspended sediment, mineral elements and bathymetry. Grain size data from the sieving of sediment samples were used to interpret suspended solids distribution in the lake. Linear correlation coefficients were used to assess the degree of dependence between rainfall and runoff inputs to the lake. Lake depth measurements in some areas of the lake serve to determine the rate of infilling. The sorting index was used to highlight the distribution and origin of sediments in the lake. The results show a degradation of the lake Ahémé ecosystem characterized by infilling of its bed, a high correlation $(r=0.90)$ between rainfall and runoff, seasonal change in physicochemical parameters (total suspended sediment decrease by $-91 \%$ ) and decrease in fish production by $135.8 \mathrm{tyr}^{-1}$. The highest mean suspended sediment concentrations in lake inputs occur during high water periods $\left(123 \mathrm{mg} \mathrm{L}^{-1}\right)$ compared to low water periods (11.2 $\left.\mathrm{mgL}^{-1}\right)$.
\end{abstract}

\section{Introduction}

Ahémé lake, in Benin western Africa, and its biodiversity attract enormous interest from people, local residents and scientists in particular (Amoussou et al., 2016). The riparian population interest is in the supply of fish resources but the ecosystem of Ahémé lake is in constant degradation. The lake dynamics and its water resources are linked to climatic and hydrological variability (Amoussou et al., 2007). Analysis of the dynamics of rivers and water bodies (Vissin, 1998) is necessary to meet the main objectives of the Global Energy and Water Experiment (GEWEX) and the Tropical Atmosphere and Hydrologic Cycle (CATCH) projects.

Eutrophication of Ahémé lake (Oyédé, 1991; Amoussou, 2004) leads to siltation, excessive concentration of chemi- cal elements, resulting in sometimes a significant presence of algae or aquatic plants, and also absence of certain plant species along the lake shores inducing hydraulic erosion.

These combined pressure factors could lead to destruction of the ecological habitats of fish species and consequently disrupt socio-economic activities. Commercial fishing is declining as a result of lower fisheries yields. Thus, the balance between natural resources and human population demands or needs is being compromised. This study aims to analyze the evolution of sedimentary and environmental parameters from 1961 to 2010 and their impacts on the ecosystem of Ahémé lake. This work brings together hydrometric, sedimentary and water quality information to help understand ecosystem changes and its impacts in Ahémé lake. 


\section{Data and methods}

\subsection{Study site}

Ahémé lake is located between $6^{\circ} 20^{\prime}$ and $6^{\circ} 40^{\prime} \mathrm{N}$ and $1^{\circ} 55^{\prime}$ and $2^{\circ} \mathrm{E}$ (Fig. 1a).

Ahémé lake is located in a depression between the Allada and Comè plateaux (Fig. 1b). The Couffo River flows into Ahémé lake from the north. Ahémé lake exchanges water in the south with the Mono and Sazoué rivers which are connected to a coastal lagoon and the Atlantic Ocean through the $24 \mathrm{~km}$ long Aho Channel. During the wet season freshwater water from Ahémé lake flows southwards in the channel to the lagoon and Atlantic Ocean. However, during the dry season the flow in the channel reverses, resulting in increased salinity in the southern part of the lake. The width of the lake is $\sim 3.4 \mathrm{~km}$ at the latitude of Guézin. The surface area of Ahémé lake is between 70 and $100 \mathrm{~km}^{2}$ in the dry and rainy seasons, respectively (Le Barbé et al., 1993).

Ahémé lake is influenced by a rather dynamic lagoon system that favors variations in $\mathrm{pH}$, temperature and salinity due to its opening on the Atlantic Ocean. The contribution of Mono River to the lake is most significant during floods or periods of high water levels (Pliya, 1980; Oyédé, 1983; Amoussou et al., 2007).

\subsection{Data}

Rainfall data from stations at Athiémé, Grand Popo, Bopa, Allada and Ouidah (see Fig. 1a) over the period 1961-2010 were extracted from the database of METEO BENIN. Flow data records of the Couffo River at Lanta and Mono River at Athiémé over the period 1961-2005 (data are not available for 2006-2010) were collected by the Hydrology Department of the Directorate General for Water. Information on sediment dynamics in Ahémé lake was available as: (1) sediment depth data collected only in 1991 and 1999 were extracted from Oyédé et al. (2007); (2) annual suspended solids concentrations measured in 1999 and 2007 at Guézin (Roche International, 1999; Amoussou et al., 2007). These were complemented by seasonal (rainy and dry) bathymetry measurements in 2003 and 2006 in Ahémé lake. Physicochemical measurements were made at localities on the east and west shores of the lake in: (1) October 2000 - pH only; and (2) September 2002 - salinity and $\mathrm{pH}$ measured using a WTW 340i handheld pH/conductivity meter. Sediment samples collected during hand dredging were analyzed by sieving using the AFNOR (French Standardization Association) method (AFNOR, 1996). Sediment weighing was carried out on a Shimadzu BX3200D (dual range: 3200/600 g and resolution: $0.1 / 0.01 \mathrm{~g})$.

\subsection{Methods}

Linear correlation coefficient were calculated between mean monthly rainfall at Athiémé, Grand Popo, Bopa, Allada and (a)
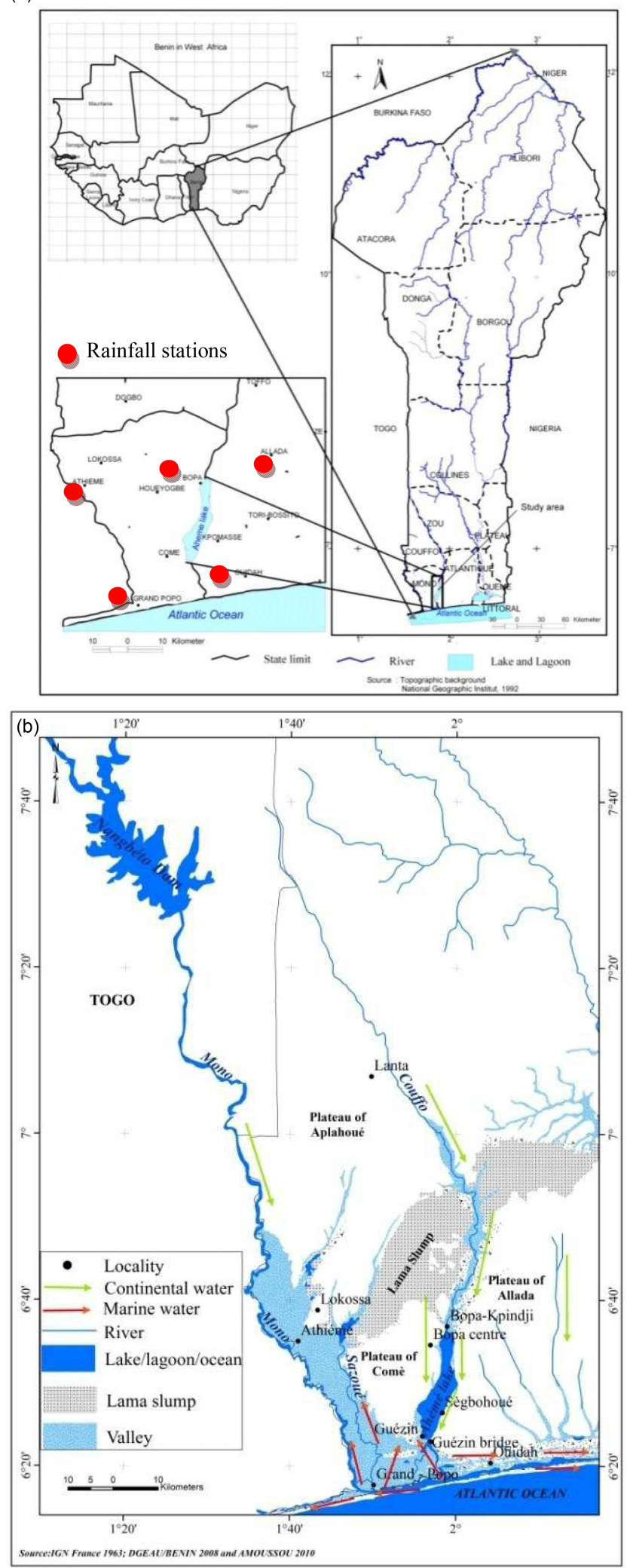

Figure 1. (a) Location of Ahémé lake in south-west of Benin. (b) The flow direction of the Mono-Couffo rivers and Ahémé lake. 


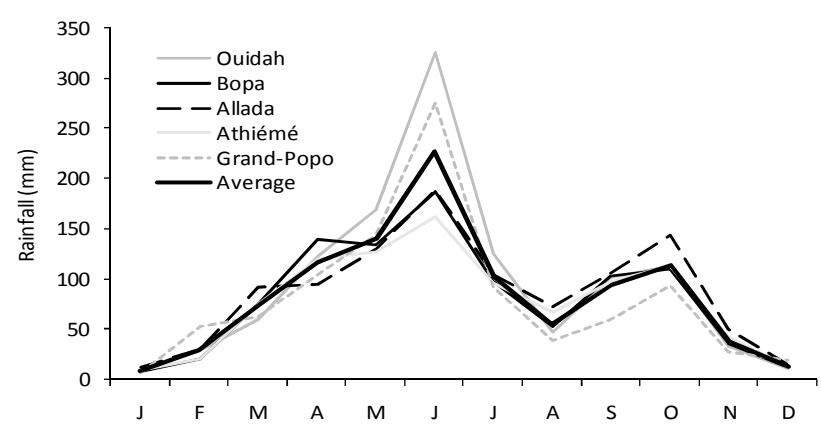

Figure 2. Mean monthly rainfall at the stations around Ahémé lake over the period 1961-2010.

Ouidah station and mean monthly flow at stations Athiémé and Lanta for the period 1961-2005 (see Figs. 2 and 3). Bravais-Pearson's correlation coefficient is calculated with 0.05 significance level.

Assessment of the sedimentary evolution of Ahémé lake was conducted to determine whether sediment depositions or erosion was occurring or whether there was sedimentary balance. The lake cross-sectional area is calculated from the depth and width of the wetted section. Thus, the decrease or increase in section area is related to depth, because from one year to the next in the same season, the width varies very little.

The bathymetry is measured by boat over $2.5 \mathrm{~km}$ at Bopa Kpindji, Bopa Centre and Sègbohouè (Fig. 1b), from the east to west bank. On this cross section, the measurement depths of Ahémé lake is doing each $2 \mathrm{~m}$ distance with graduated wooden ruler on dry and rainy seasons.

These measurements referred to a standard water level $(0.5 \mathrm{~m})$ at the gauging station under Guézin bridge (Fig. 1b) and formed the basis for estimating the sediment depth data shown in Table 1. The Sorting index $\left(S_{0}\right)$ was used to determine the distribution and origin of sediments in the lake through the formula:

$S_{0}=\frac{q_{3}}{q_{1}}$

where $q_{1}$ and $q_{3}$ are the first and third quartile, respectively, of the grain size distribution.

- If $S_{0}=1$ or close to $1:$ the sediment is homogeneous (well sorted), corresponding to a steep gradient of the grain size curve (Ben Amor et al., 2003; Marc and Emblanch, 2005);

- If $S_{0}<$ or $>1$ : the sediment is poorly sorted out, corresponding to a low gradient of the grain size curve (Ben Amor et al., 2003; Marc and Emblach, 2005).

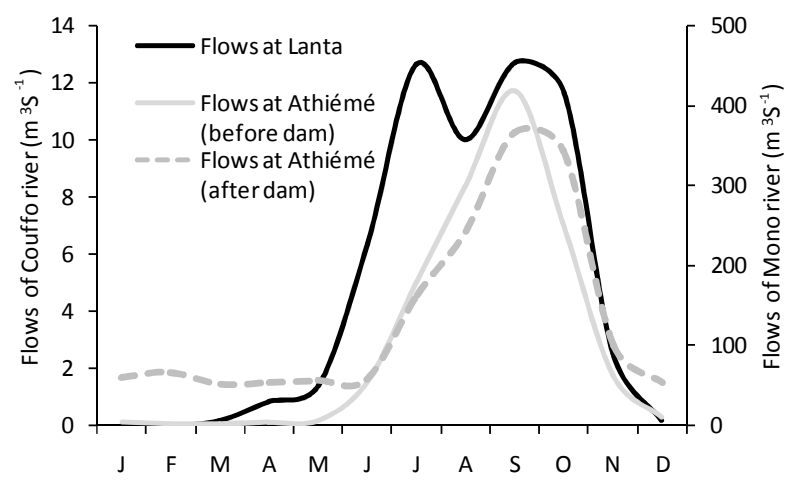

Figure 3. Mean monthly flow of the Mono River at Athiémé and Couffo River at Lanta linking Ahémé lake over the period 19612005.

\section{Results and discussion}

\subsection{Rainfall and river flow variation}

Figures 2 and 3 show the mean monthly rainfall and flows of rivers feeding the Ahémé ecosystem. The annual rainfall regime is bimodal, characterized by an important supply of water over May-July (rainy season) and September-October (small rainy season).

This seasonal climate variability results in the transport of dried sediment from the banks into Ahémé lake. Sediment and water inflow from the Couffo River to Ahémé lake is less important than that of the Mono River which has a higher flow (annual mean flow is $5.1 \mathrm{~m}^{3} \mathrm{~s}^{-1}$ at Lanta and $114.4 \mathrm{~m}^{3} \mathrm{~s}^{-1}$ at Athiémé over 1961-2005).

Correspondence of flows with the rainy season confirms the high rainfall vs. flow Bravais-Pearson's correlation coefficient $(r=0.90)$ in the study area.

Moreover, the lake receives a large volume of water during September-October when the rivers entering the lake reach their maximum annual flow and also contain their highest suspended solids concentration as reported by Amoussou (2004). The Couffo river has much greater seasonal variability in flow compared to the Mono river especially since construction of the dam on the Mono river at Nangbéto $\left(7^{\circ} 25^{\prime} 25.40^{\prime \prime} \mathrm{N} ; 1^{\circ} 26^{\prime} 5.82^{\prime \prime} \mathrm{E}\right)$ in September 1987. The difference in the hydrological flow regimes in the Couffo and Mono rivers and the effect of the Nangbéto dam on dry season flow are evident in Fig. 3. Base flow in December to April at Athiémé was $4.22 \mathrm{~m}^{3} \mathrm{~s}^{-1}$ before the dam construction and increased to $57.26 \mathrm{~m}^{3} \mathrm{~s}^{-1}$ after the dam construction. The dam has had a major impact on water and sediment flows from the Mono river to the Ahémé lake ecosystem, including increased bank erosion downstream of the dam (Oyédé, 1991; Amoussou, 2010). 
Table 1. Sedimentation evolution in some parts of the Ahémé lake from 1991 to 1999.

\begin{tabular}{lrrrr}
\hline Site & \multicolumn{4}{c}{ Sectional areas of sediment $\left(\mathrm{m}^{2}\right)$} \\
\cline { 2 - 5 } & 1991 & 1999 & $\begin{array}{r}\text { Difference } \\
(1991-1999)\end{array}$ & $\begin{array}{r}\text { Variation } \\
\text { rate }(\%)\end{array}$ \\
\hline Bopa Kpindji & 2405 & 2499 & +94 & 3.9 \\
Bopa Centre & 5164 & 4919 & -245 & -4.7 \\
Sègbohouè & 2899 & 2744 & -155 & -5.3 \\
\hline
\end{tabular}

Source: Oyédé et al. (2007)

\subsection{Morphodynamics of Ahémé lake}

Data from the years 1991 and 1999 (Oyédé et al., 2007) revealed declining water depths in some areas of Ahémé lake. Comparison of the depths between 1991 and 1999 in a few areas of the lake, in the north (Bopa Kpindji and Bopa Centre) and the south (Sègbohouè), revealed infilling (Table 1) from the east bank to the west bank. In the north of the lake, there was erosion at Bopa Centre from 1991 to 1999, together with deposition at Bopa Kpindji, especially on the eastern bank.

Infilling of Ahémé lake, as indicated by some of the data presented here, is one of the factors of the lake impoverishment contributing to fish species migration and ecosystem degradation.

Suspended solid inflows to the lake are more important in the rainy season than in the dry season, as demonstrated by measurements carried out by Roche International (1999) and Amoussou et al. (2007), who showed that at Guézin bridge, the daily suspended solids concentration measured during the rainy season varied from 81 to $165 \mathrm{mgL}^{-1}$ (mean $\sim 123 \mathrm{mg} \mathrm{L}^{-1}$ ) while in the dry season they range from 3.5 to $19 \mathrm{mg} \mathrm{L}^{-1}$ (mean $\sim 11.2 \mathrm{mg} \mathrm{L}^{-1}$ ).

\subsection{Granulometric analysis}

Figure 4 shows the parabolic curves of granulometric variation for sediment samples from the coastal lagoon and Ahémé lake, based on the sediment weight data transformed into a cumulative percentage.

The proportion of sands ( $>0.5 \mathrm{~mm}$ diameter) is greater $(80 \%)$ in the coastal lagoon than in Ahémé lake (40\%). The particle size range is narrower in Ahémé lake and is dominated by fine particles, indicating the transport of particles in suspension. These results are consistent with those obtained by Yalin and Karahan (1979) on the secondary tributary of the Loire river and by Fournier (2004) on the Durance river, both in France, and by Degoutte (2006) on embankment dams. The textural heterogeneity of the sediments is also due to their origin: either from the crystalline basement geology or sedimentary rocks affected by erosion, or from the sea.

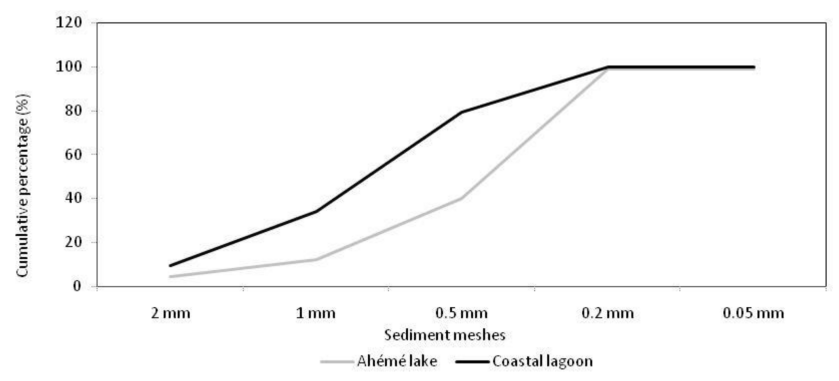

Figure 4. Sediment granulometric curves in the coastal lagoon and Ahémé lake (Source: Amoussou et al., 2016).

Values of the Sorting Index $\left(S_{0}\right)$ were $>1$, showing that deposited sediments are poorly sorted in both Ahémé lake $\left(S_{0}=2.15\right)$ and in the lagoon $\left(S_{0}=1.71\right)$. This can be explained by the effect of a range of processes, including low roughness of the floodplain, flocculation due to saline conditions at high tide, solid inputs generated by anthropogenic activities and the transport and deposition of the majority of sediment as bed load mobilised during the rainy season. These results are consistent with those of Cerdan et al. (2002) and Amoussou (2010), who reported that, because of the absence of vegetation, in the rainy season sediment particles are mobilized and deposited on the lake bed, modifying the lithofacies of the bottom. Large sediment particles are deposited on the river banks whilst finer sediment particles are transported by the river into Ahémé lake.

\subsection{Evolution of physicochemical parameters}

Salinity measurements at the entrance to the lake (Guézin first bridge) in the north (Bopa Agonsa) and on both banks of Ahémé lake in September 2002 (Fig. 5) show high salinity even during the rainy season. This is caused by the quasipermanent opening of the Mono River mouth on the coastal lagoon. It could also be attributed to a decrease of rainfall around the lake in the years $2000(-26$ to $-29 \%), 2001(-8$ to $-13 \%)$ and 2002 ( -10 to $-15 \%)$, compared with the annual mean rainfall for the period 1961-2010 $(968.42 \mathrm{~mm})$, providing less rainfall for dilution of salinity. Salinity values measured in the lake in September 2002 (at the beginning of the floods of the Mono and Couffo rivers, where salinity is almost zero) are much higher than those recorded in other parts of the drainage basin (Oyédé, 1981, 1983, 1991) and other rivers in Benin (Amoussou, 2003; Amoussou et al., 2007).

Increasing salinity can result in enhanced flocculation of terrigenous sediment in the lake and subsequent deposition within the lake, contributing to sediment infilling.

Analysis of the pH data (Fig. 6) allows assessment of the suitability of the lake water quality for aquatic ecology and fish species. The mean $\mathrm{pH}$ at the localities ranges from 7.2 to 8.2 in October 2000 , indicating a basic environment dur- 

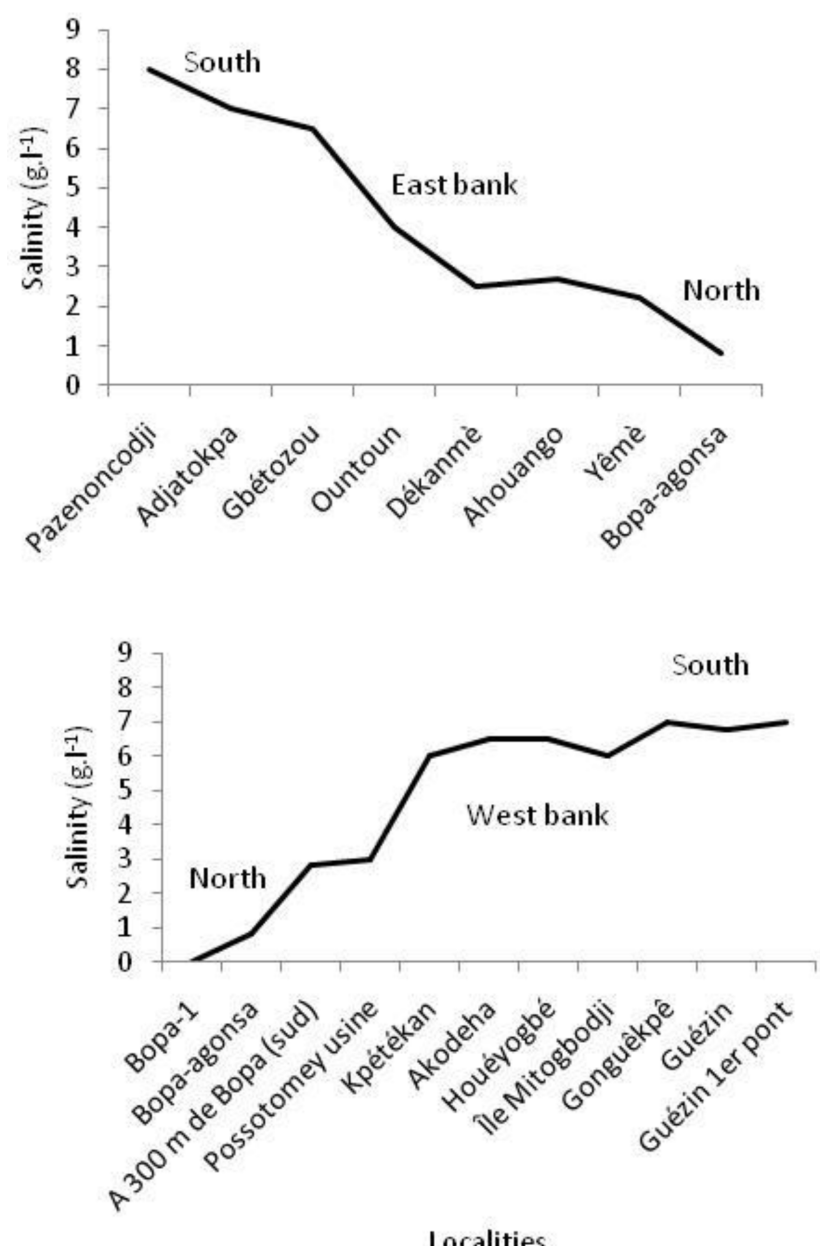

Figure 5. Spatial variation in salinity from South to North on the eastern and western bank of Ahémé lake in September 2002 (Source: Amoussou, 2003).

ing high water periods. In the lake area, $\mathrm{pH}$ is quite variable, as also shown by Houadégla (1991) in Nokoue lake $\left(6^{\circ} 25^{\prime} 23.71^{\prime \prime} \mathrm{N} ; 2^{\circ} 26^{\prime} 26.30^{\prime \prime} \mathrm{E}\right)$ in south-east Benin, which is also in the subequatorial climate domain.

Lake $\mathrm{pH}$ values depend on the time and location of measurement, since they can be affected by solar insolation, intensity of chlorophyll assimilation, respiration of animals and metabolism of lower aquatic organisms. The high $\mathrm{pH}$ at Guézin (8.2) is attributed to the fact that saline marine waters necessarily pass through this point before reaching the lake.

Degradation of the Ahémé lake ecosystem due to eutrophication, low dissolved oxygen concentration (Dèdjiho et al., 2013; Dimon et al., 2014) and over-fishing resulting in lower fish reproduction rates (not demonstrated in this study) has affected fish production (Fig. 7) with a decline in annual fish production from $6298 \mathrm{t}$ in 1987 to $1813 \mathrm{t}$ in 2000.

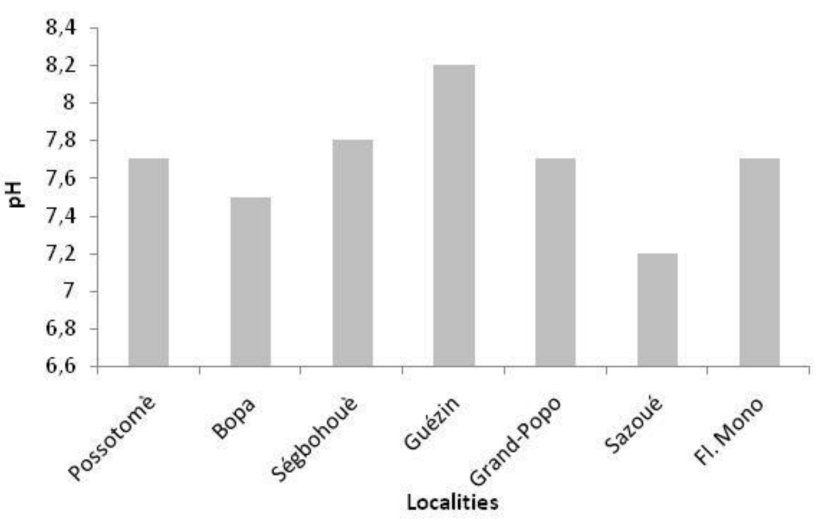

Figure 6. Spatial variation of $\mathrm{pH}$ measured in Ahémé lake in October 2000 (Source: PAZH, 2002).

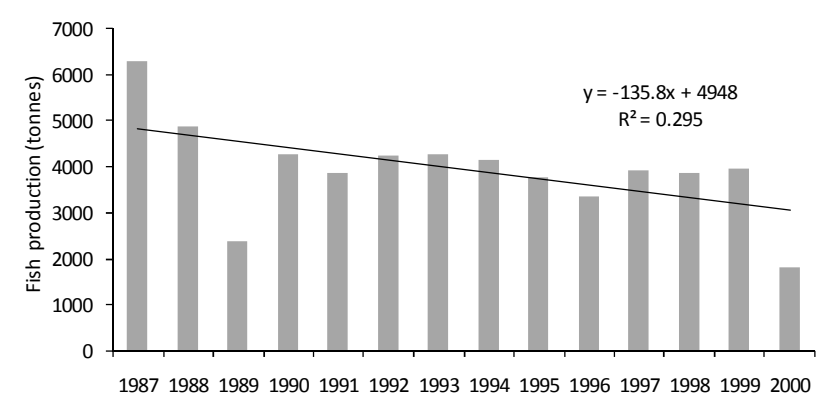

Figure 7. Annual fish production in Ahémé lake from 1987 to 2000 (Source: Fish farming Directorate, 2002).

\section{Conclusion}

Ahémé lake is characterized by a bimodal rainfall regime (two dry seasons and two alternating rainy seasons) and the unimodal flow regime of the Mono (with increased base flow as the result of dam construction) and Couffo Rivers. The high flows coincide with the heavy rains occurring in the lake's catchment. The strong flow / rain relationship reflects the dependence of the flow on rainfall and influences the variation of water physicochemical parameters. Infilling of the lake is confirmed by the continuing decrease in lake depth by sediment with a narrower range of particle size in the lake than in the coastal lagoon.

Data availability. The data are not publicly accessible:

- Climatology data are been propriety of Agence Météo Benin,

- Fish data are been propriety of Fish direction.

Competing interests. The authors declare that they have no conflict of interest. 
Special issue statement. This article is part of the special issue "Water quality and sediment transport issues in surface water". It is a result of the IAHS Scientific Assembly 2017, Port Elizabeth, South Africa, 10-14 July 2017.

Acknowledgements. Authors wish to thank also the Agency of Météo Benin and the Fish directorate for providing data. The authors wish to thank the Associated Editor (Kate Heal), and an anonymous reviewer for their useful comments on the manuscript.

Edited by: Kate Heal

Reviewed by: two anonymous referees

\section{References}

AFNOR: NF P94-056. Sols: reconnaissance et essais. Analyse granulométrique. Méthode de tamissage à sec après lavage. Soil: investigation and testing. Granulometric analysis. Dry sieving method after washing, France, 15 p., 1996.

Amoussou E.: Dynamique hydro-sédimentaire et mutations des écosystèmes du lac Ahémé. Mémoire de maitrise, DGAT/FLASH/UAC, 103 p., 2003.

Amoussou, E.: Systèmes traditionnels de gestion durable du lac au Bénin, in: Développement durable: leçons et perspectives, Acte de Colloque AUF Ouagadougou, Burkina Faso, 263-270, 2004.

Amoussou, E.: Variabilité pluviométrique et dynamique hydrosédimentaire du bassin-versant du complexe fluvio-lagunaire Mono-Ahémé-Couffo (Afrique de l'Ouest), PhD thesis, Université de Bourgogne, Dijon, CRC - CNRS- UMR5210, 313 p., 2010.

Amoussou, E., Vissin, E. W., Houssou, C. S., and Boko, M.: Changes in Physicochemical parameters and productivity of Ahémé lake, in: 14th Stockholm Water Symposium: Drainage basin management-regional approaches for food and urban security, Abstract volume, 2004, Stockholm Water Symposium, 159$160,2004$.

Amoussou, E., Oyédé, L. M., and Boko, M.: Variabilité pluviométrique et flux de turbidité dans le complexe Chenal Ahôlac Ahémé au Bénin (Afrique de l'Ouest), Actes du XXème colloque AIC, in: Climat, Tourisme et Environnement de Carthage, Carthage, Tunisie, 81-86, 2007.

Amoussou, E., Totin, V. S. H., Tohozin, Y. A., Oyédé, M. L., and Boko, M.: Traditional adaptation strategies to hydrosystem degradation for sustainable management of the Ahémé lake in Benin (West Africa), European Scientific Journal of European Scientific Institue (ESI), 12, 352-365, 2016.

Ben Amor, R., Brahim, M., and Gueddari, M.: Essai d'interprètation de la dynamique sédimentaire par l'analyse granulométrique et minéralogique au large du Golfe de Gabès, Bull. Inst. Natn. Sci. Tech. Mer de Salammbô, 30, 143-151, 2003.

Cerdan, O., Le Bissonnais, Y., Souchere, V., Martin, P., and Lecomte, V.: Sediment concentration in interrill flow interactions between solid surface conditions, vegetation and rainfall, Earth Surf. Proc. Land., 27, 193-205, https://doi.org/10.1002/esp.314, 2002.
Dèdjiho, C. A., Mama, D., Tomètin, L., Nougbodé, I., Chouti W., Sohounhloué, C. K. D., and Boukari, M.: Évaluation de la qualité physico-chimique de tributaires d'eaux usées du lac Ahémé, Benin, J. Appl. Biosci., 70, 5608-5616, 2013.

Degoutte, G.: Diagnostic, aménagement et gestion des rivières: hydraulique et morphologie fluviales appliquées, Editions Tec \& Doc, Lavoisier, France, 394 p., 2006.

Dimon, F., Dovonou, F., Adjahossou, N., Chouti, W., Mama, D., Alassane, A., and Boukari, M.: Caractérisation physicochimique du lac Ahémé (Sud Bénin) et mise en relief de la pollution des sédiments par le plomb, le zinc et l'arsenic, J. Soc. Ouest-Afr. Chim., 37, 36-42, 2014.

Fish farming Directorate: Annual fish production in Ahémé lake from 1987 to 2000, cotonou, Bénin, 10 p., 2002.

Fournier, L.: Modélisation de la production des apports sédimentaires dans le bassin de la Durance, Mémoire de DEA, LNHE, CRD-EDF, Université Pierre et Marie Curie, Paris, France, 56 p., 2004.

Houadégla, W. A.: Rythmes climatiques et productions halieutiques au Bénin: cas du "lac" Nokoué, Mémoire de maîtrise en DGAT/FLASH/UNB, 126 p., 1991.

Le Barbé, L., Alé, G., Millet, B., Texier, H., Borel, Y., and Gualde, R.: Les ressources en eaux superficielles de la République du Bénin, Edition ORSTOM, France, 540 p., 1993.

Marc, V. and Emblanch, C.: Cours de méthode de calcul des paramètres granulométriques, France, 2005.

Oyédé, L. M.: Sédimentation margino-littoral au débouché du "lac" Ahémé (Bénin Afrique de l'Ouest), Mémoire de DEA, Science de la Terre, Dijon, 44 p., 1981.

Oyédé, L. M.: Un exemple de sédimentation biodétrique quaternaire dans le domaine margino - littoral en climat tropical humide: le "lac" Ahémé - (Bénin - Afrique de l'Ouest), PhD thesis, Université de Dijon, Paris, 171 p., 1983.

Oyédé, L. M.: Dynamique sédimentaire actuelle et messages enregistrés dans les séquences quartenaires et néogènes du domaine margino littoral du Bénin (l'Afrique de l'Ouest), PhD thesis, Université de Bourgogne, Paris, 302 p., 1991.

Oyédé, L. M., Kaki, C., and Laïbi, R.: Environnement sédimentaire, morphologie et faciès du lac Ahémé dans le complexe lagunaire sud-ouest béninois, Annales des Sciences agronomiques du Bénin, 9, 75-98, 2007.

PAZH: La pollution dans les zones humides du Sud-Bénin: état actuel, impacts, stratégies de suivi et de lutte. Rapport Intérimaire, 111, 42 p., 2002.

Pliya, J.: La pêche dans le Sud-Ouest du Bénin. Etude de géographie appliquée sur la partie continentale et maritime, AGECOOP, Paris, 293 p., 1980.

Roche International: Etude de projet d'aménagement des plans d'eau du Sud-Bénin, Volume III, Tome III, Rapport final, 101 p. + annexes, 1999.

Vissin, E. W.: Contribution à l'étude du fonctionnement hydrologique du bassin de la Sota, Mémoire de maîtrise, FLASH/UNB, 80 p. + annexes, 1998.

Yalin, M. S. and Karahan, E.: Inception of sediment Transport, J. Hydr. Eng. Div.-ASCE, 105, 1433-1443, 1979. 